\author{
Vladimir N. Syzrantsev \\ Professor \\ Tyumen Industrial University \\ Institute of geology and oil and gas \\ production \\ Russia \\ Ksenia V. Syzrantseva \\ Professor \\ Tyumen Industrial University \\ Institute of geology and oil and gas \\ production
}

\section{Study of Geometric Characteristics of the Arc Teeth Semi-Rolled Cylindrical Gear Meshing}

In the conditions of unbraced machine body parts, arc teeth cylindrical gears have a higher load capacity, durability and reliability as well as the ability to compensate for the twist angle by self-adjustment of one of the wheels compared to straight and helical teeth gears. Use of such gears in a semi-rolled version allows simplifying significantly the technological process of cutting wheels and making gears with large gear ratios. In this article, mathematical models of wheel and gear arc teeth forming process are built for a semi-rolled cylindrical gear. The geometric characteristics of the gear arc teeth meshing in the presence of errors in the wheel and gear relative position, required to solve the problem of calculating the gear load capacity and durability, have been determined.

Keywords: semi-rolled cylindrical gear, arc teeth, lines of action

\section{INTRODUCTION}

The load capacity and durability of the most common cylindrical gears with straight and helical teeth depend on the errors in the relative position of the usable flanks of the contacting teeth. The twist angle is the dominant error. The angle is a composition of two random variables: the gear elements manufacturing and assembly error and gear parts and bodies deformation due to the power flow. Since the second component of the twist angle for energy-saturated machines often significantly exceeds the gear manufacturing and assembly tolerances, in many cases, it is not possible to achieve the required performance and durability of cylindrical gears.

An effective way to solve the problem is to use arc teeth cylindrical gears in the transmissions of tractors, locomotives, coal harvesters and other energy-saturated machines (Figure 1) [1,2].

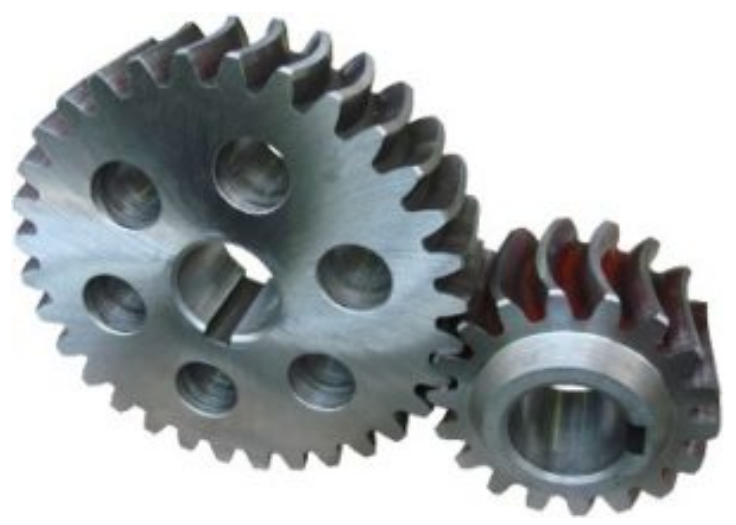

Figure 1. Arc teeth cylindrical gear

Spiral (circular, arc) teeth in bevel gears have been used since the beginning of the past century. For their production, Gleason, Klingelnberg, Oerlikon specialists

Received: February 2021, Accepted: March 2021

Correspondence to: Prof. Ksenia Syzrantseva

Tyumen Industrial University,

Volodarskogo st. 38, 625000 Tyumen, Russia

E-mail:kv.syzr@gmail.com

doi: 10.5937/fme2102367S

(C) Faculty of Mechanical Engineering, Belgrade. All rights reserved have developed various cutting methods and created task-specific gear cutting machines and tools [3-6].

When cutting teeth on Gleason machines, they use a circular cutting head implementing the Face Milling Method [7-9], or a multi-thread cutting head implementing the Face Hobbing Method [8, 10]. Klingelnberg and Oerlikon gear cutting machines implement methods for cutting cyclo-palloid bevel wheels [11-15].

In this case, either bevel gear hobs or special multithread cutting heads are used as the tools. Cutting cyclopalloid teeth is performed with the Continuous Generation Method. The bevel wheel meshing in all the proposed methods is performed on the basis of the general gear wheel.

A significant reduction in the cost of the bevel gear manufacture in their mass production on Gleason machines is achieved by using semi-rolled bevel gears [1618]. In this method, cutting the wheel teeth is carried out without generating process. Gleason specialists have developed the FORMATE and HELIXFORM Methods in this scope. Despite the more difficult task of finding the optimal geometry $[16,18]$, the technology of manufacturing such gears is more advanced.

Currently, a number of methods are proposed for cutting cylindrical gear arc teeth, which differ in the tools used and shaping movements [19-27]. The methods used for cutting bevel wheel spiral teeth are the basis of most of these methods. Arc teeth cylindrical gear meshing in the proposed methods is based on the counterpart rack. In this case, the helix angle of the arc tooth in its midsection is equal to zero. In [28-30], options for cutting cylindrical wheel arc teeth with circular cutting heads by means of generating with a single division on CNC machines are presented.

The analysis of the works related to the study of geometry, contact and bending strength of arc teeth gears shows that all of them are dedicated to generating cylindrical gears. For semi-rolled cylindrical gears, the issues of forming arc teeth and their meshing contact have not been considered. This does not allow to implement maximum gear ratios for cylindrical gears and increase the durability of high-load drives of modern machines by using self-adjusting arc teeth cylindrical gears. 


\section{FORMING WHEEL AND GEAR ARC TEETH FLANKS OF THE SEMI-ROLLED CYLINDRICAL GEAR}

According to the methods of forming semi-rolled bevel gears [16-18], in the manufacture of semi-rolled cylindrical gears, the arc teeth of the wheel are cut by the single division method without generating with a cutting head, the generating surface of which is a straight circular cone. In this case, the usable flank of the wheel arc tooth will also be the surface of the straight circular cone. Forming the usable flank of the gear arc tooth is possible in two different ways. According to the first method, the gear arc tooth is processed with a tool (circular cutting head) on the basis of the counterpart rack. To obtain the gear tooth profile mated to the profile of the wheel arc tooth, the counterpart rack is provided with some overtravel, consistent with the rotation of the gear around its axis.

To realize this method, a special machine tool attachment that implements the overtravel of the machine table from the copy templet is required. The shape of the templet is calculated depending on the geometric parameters of the gear tooth profile. The second method of forming the gear arc tooth is carried out on the basis of the generating gear. In this method, the flank of the gear arc tooth is the enveloping flank of the wheel tooth at a given relative movement of the wheel and gear in the transmission, and its implementation is possible on modern four-axes CNC machines $[29,30]$. The gear formed according to this scheme, in the absence of errors in the relative position of the gear and wheel, is matched and theoretically accurate.

The generating surface of the cutting head (straight circular cone) can be described in coordinate system $S_{p}\left(x_{p}, y_{p}, z_{p}\right)$ rigidly connected to it (Figure 2$)$, as follows:

$$
x_{p}=g \cdot \cos \vartheta ; y_{p}=u \cdot \cos \alpha_{0} ; z_{p}=g \cdot \sin \vartheta,
$$

where, $g=u \cdot \sin \alpha_{0}-r_{g 2}, u, \vartheta$ are linear and angular parameters of the generating surface; $\alpha_{0}$ is a basic profile angle; $r_{\mathrm{g} 2}$ is a calculated radius of the cutting head rotating around axis $y_{\mathrm{p}}$ of coordinate system $S_{p}\left(x_{p}, y_{p}, z_{p}\right)$.

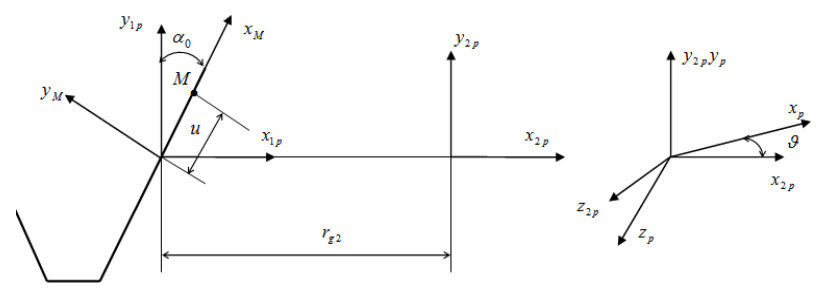

Figure 2. Cuitting head generating surface

Taking into account the way of forming the usable surface of the wheel tooth, radius-vector $\bar{r}_{p}\left(x_{p}, y_{p}, z_{p}\right)$ is to be written into coordinate system $S_{2}\left(x_{2}, y_{2}, z_{2}\right)$ that is rigidly connected to the wheel:

$$
\widetilde{r}_{2}=\widetilde{A}_{2, p} \cdot \widetilde{r}_{p}
$$

where, $\widetilde{r}_{2}, \widetilde{r}_{p}$ are columns matrixes made up of vector radii coordinates $\bar{r}_{2}$ and $\bar{r}_{p} ; \widetilde{A}_{2, p}$ is a fourth-order matrix describing the transition from coordinate system $S_{p}\left(x_{p}, y_{p}, z_{p}\right)$ to system $S_{2}\left(x_{2}, y_{2}, z_{2}\right)$; its elements $b_{i j}$, i,j $=$ $\overline{1,4}$, based on Figure 3 , have the following values:

$$
\begin{aligned}
& b_{11}=b_{22}=b_{33}=b_{44}=1 \\
& b_{12}=b_{13}=b_{21}=b_{23}=b_{31}=b_{32}=b_{34}=0 \\
& b_{41}=b_{42}=b_{43}=0 ; b_{14}=r_{g 2} ; b_{14}=R_{w 2}
\end{aligned}
$$

where, $R_{w 2}$ is the radius of the initial circle of the wheel.

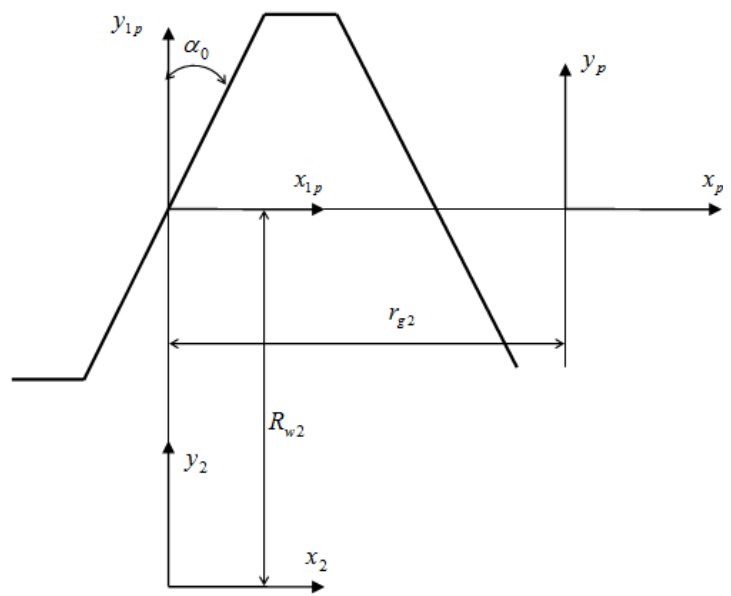

Figure 3. Coordinate systems to define elements of matrix $\widetilde{A}_{2, p}$

We find the projections of the wheel radius-vector $\bar{r}_{2}\left(x_{2}, y_{2}, z_{2}\right)$ based on (1) and (3), opening equation (2):

$$
\begin{aligned}
& x_{2}=g \cdot \cos \vartheta+r_{g 2} ; y_{2}=u \cdot \cos \alpha_{0}+R_{w 2} \\
& z_{2}=g \cdot \sin \vartheta
\end{aligned}
$$

Projections $m_{2 x}, m_{2} y, m_{2 z}$ of the surface normal unitary vector (4) have the form:

$$
\begin{aligned}
& m_{2 x}=\cos \alpha_{0} \cdot \cos \vartheta ; m_{2 y}=-\sin \alpha_{0} ; \\
& m_{2 z}=\cos \alpha_{0} \cdot \sin \vartheta
\end{aligned}
$$

Expressions (4) and (5) describe radius-vector $\bar{r}_{2}\left(x_{2}, y_{2} z_{2}\right)$ and normal unitary vector $\bar{m}_{2}$ $\left(m_{2 x}, m_{2 y}, m_{2 z}\right)$ of the usable flank of the concave side of the wheel arc tooth in coordinate system $S_{2}\left(x_{2}, y_{2}, z_{2}\right)$.

To determine the usable flank of the concave side of the gear arc tooth, we use the fact that it is a oneparameter envelope of the family of wheel tooth usable flanks in a given relative motion - the rotation of the gear and wheel with constant gear ratio $i=z_{2}^{*} / z_{1}^{*}=$ const $, z_{1}^{*}, z_{2}^{*}$ are the numbers of teeth of the gear and wheel.

Using the methods of the spatial meshing theory [31], we write the equation of the gear tooth usable flank in the form:

$$
\widetilde{r}_{1}\left(u, \vartheta, \varphi_{2}\right)=\widetilde{A}_{1,2}\left(\varphi_{2}\right) \widetilde{r}_{2}(u, \vartheta) ; f\left(u, \vartheta, \varphi_{2}\right)=0 .
$$


Here: $\widetilde{A}_{1,2}\left(\varphi_{2}\right)$ is a fourth-order matrix describing the transition from coordinate system $S_{2}\left(x_{2}, y_{2}, z_{2}\right)$ to coordinate system $S_{1}\left(x_{1}, y_{1}, z_{1}\right)$ rigidly connected to the gear (Figure 4$) ; \varphi_{2}$ is the angle of the wheel rotation when forming the gear tooth flank, associated with the angle of its rotation $\varphi_{1}$ through gear ratio $i$ :

$$
\varphi_{1}=i \cdot \varphi_{2}=\left(z_{2}^{*} \cdot \varphi_{2}\right) / z_{1}^{*}
$$

The meshing equation [31] is the last written in (6).
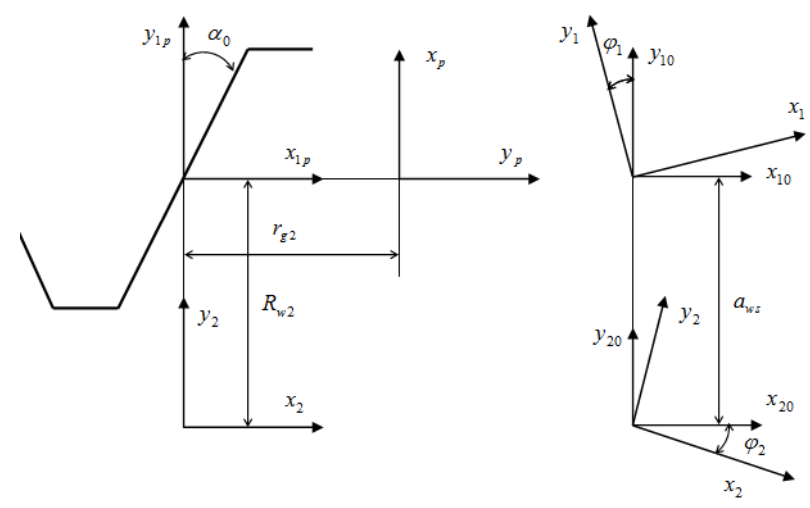

Figure 4. Coordinate systems to define elements of matrix $\widetilde{A}_{1,2}\left(\varphi_{2}\right)$

Using Figure 4, we define elements $a_{i j}, i=\overline{1,4}$; $j=\overline{1,4}$ of matrix $\widetilde{A}_{1,2}\left(\varphi_{2}\right)$ :

$$
\begin{gathered}
a_{11}=\cos \left(\phi_{1}+\phi_{2}\right) ; \quad a_{12}=\sin \left(\phi_{1}+\phi_{2}\right) ; a_{13}=0 ; \\
a_{14}=-a_{w s} \sin \phi_{1} ; a_{21}=-\sin \left(\varphi_{1}+\varphi_{2}\right) ; \\
a_{22}=\cos \left(\varphi_{1}+\varphi_{2}\right) ; \quad a_{23}=0 ; \\
a_{24}=-a_{w s} \cos \phi_{1} ; \quad a_{31}=a_{32}=0 ; \quad a_{33}=1 ; \\
a_{34}=0 ; \quad a_{41}=a_{42}=a_{43}=0 ; \quad a_{44}=1,
\end{gathered}
$$

where, $a_{w s}$ is the center distance in the machine meshing of the gear and the generating gear.

Opening matrix equation (6), with respect to (4) and (8), we find the expressions for radius-vector $\bar{r}_{1}\left(x_{1}, y_{1}, z_{1}\right)$ projections of the usable flank of the gear arc tooth:

$$
\begin{aligned}
& x_{1}=A \cdot \cos \left(\phi_{1}+\phi_{2}\right)+B \cdot \sin \left(\phi_{1}+\phi_{2}\right)-a_{w s} \cdot \sin \phi_{1} \\
& y_{1}=-A \cdot \sin \left(\phi_{1}+\phi_{2}\right)+B \cdot \cos \left(\phi_{1}+\phi_{2}\right)-a_{w s} \cdot \cos \phi_{1} \\
& z_{1}=\sin \vartheta\left(u \cdot \sin \alpha_{0}-r_{g 1}\right)
\end{aligned}
$$

where: $A=g \cdot \cos \vartheta+r_{g 1} ; B=u \cdot \cos \alpha_{0}+R_{2 w}$.

We obtain the meshing equation by the method described in [31]. According to the method, the meshing equation is written in the form:

$$
f\left(u, \vartheta, \phi_{2}\right)=\bar{V}_{\phi} \cdot \bar{m}_{2}=0,
$$

where, $\bar{V}_{\varphi}$ is the vector analog of the relative speed, $\bar{m}_{2}$ is the normal unitary vector of the generating gear (5).

Projections $V_{\varphi x}, V_{\varphi y}, V_{\varphi z}$ of vector $\bar{V}_{\varphi}$ are calculated using the expression [31]:

$$
\tilde{V}_{\phi}=\tilde{A}_{1,2}^{-1} \cdot \frac{d \tilde{A}_{1,2}}{d \phi_{2}} \cdot \tilde{r}_{2} .
$$

Here, $\widetilde{V}_{\varphi}$ is a column matrix composed of projections $V_{\varphi x}, V_{\varphi y}, V_{\varphi z}$.

Opening dependence (10) based on (5), (11) and (8), we obtain:

$$
\begin{aligned}
& f\left(u, \vartheta, \phi_{2}\right)=u \cdot \cos \vartheta \cdot(1+i)+ \\
& +\cos \alpha_{0} \cos \vartheta \cdot\left[R_{2 w}(1+i)-i a_{w s} \cos \phi_{2}\right]+ \\
& +\sin \alpha_{0}\left[(1+i) r_{g 1}(1-\cos \vartheta)-i a_{w s} \sin \phi_{2}\right]=0
\end{aligned}
$$

Dependences (9) jointly with equation (12) fully describe the geometry of the usable flank of the gear arc tooth concave side.

The normal unitary vector projections of the gear arc tooth usable flank are defined based on the matrix equation:

$$
\tilde{m}_{1}\left(u, \vartheta, \phi_{2}\right)=\tilde{A}_{1,2}\left(\phi_{2}\right) \tilde{m}_{2}(u, \vartheta)
$$

We open expression (13) based on (5) and (8) and find:

$$
\begin{aligned}
& m_{1 x}=\cos \left(\phi_{1}+\phi_{2}\right) \cos \alpha_{0} \cos \vartheta- \\
& -\sin \alpha_{0} \sin \left(\phi_{1}+\phi_{2}\right) \\
& m_{1 y}=-\sin \left(\phi_{1}+\phi_{2}\right) \cos \alpha_{0} \cos \vartheta- \\
& -\sin \alpha_{0} \cos \left(\phi_{1}+\phi_{2}\right) \\
& m_{1 z}=\cos \alpha_{0} \cos \vartheta
\end{aligned}
$$

\section{CALCULATION OF LINES OF ACTION IN SEMI- ROLLED CYLINDRICAL GEAR WHEEL AND GEAR ARC TEETH MESHING}

Meshing of semi-rolled cylindrical gear arc teeth in the presence of errors in the relative position of the wheel and gear in transmissions belongs to the class of nonenveloping meshing $[9,16]$. When the specified errors are absent, the contact between the active flanks of the gear and wheel teeth occurs at the points of the tooth transverse midsection. In this tooth section, the helix angle is zero. When the contact is localized in the longitudinal direction of the teeth, the gear is matched to eliminate their interference.

We consider the derivation of mathematical relationships to determine the coordinates of the contact points on the active flanks of the arc teeth of the wheel and gear installed with errors. The solution of this problem allows evaluating the arc teeth semi-rolled cylindrical gear sensitivity to errors in the relative position of the gear and wheel for the purpose of scientific substantiation of the tolerances for the error values. On the other hand, knowing the contact point coordinates is required to solve the problem of calculating the gear contact loading.

The relationships of the radius-vectors and normal unitary vectors of the gear and wheel arc teeth flanks are initial parameters for solving the problem. In the designation of vectors and normal unitary vectors, we use superscript "1", if they are defined in coordinate 
system $S_{1}\left(x_{1}, y_{1}, z_{1}\right)$, and superscript "2", if they are defined in coordinate system $S_{2}\left(x_{2}, y_{2}, z_{2}\right)$.

Based on relationships (4) and (5), the projections of radius-vector $\bar{r}_{2}^{2}\left(u_{2}, \vartheta_{2}\right)$ and normal unitary vector $\bar{m}_{2}^{2}\left(\vartheta_{2}\right)$ of the wheel arc tooth flank in coordinate system $S_{2}\left(x_{2}, y_{2}, z_{2}\right)$, rigidly connected to the wheel, will have the form:

$$
\begin{aligned}
& x_{2}\left(u_{2}, \vartheta_{2}\right)=\cos \vartheta_{2}\left(u_{2} \cdot \sin \alpha_{0}-r_{g 2}\right)+r_{g 2} \\
& y_{2}\left(u_{2}\right)=u_{2} \cdot \cos \alpha_{0}+R_{w 2} \\
& z_{2}\left(u_{2}, \vartheta_{2}\right)=\sin \vartheta_{2}\left(u_{2} \cdot \sin \alpha_{0}-r_{g 2}\right) \\
& m_{2 x}\left(\vartheta_{2}\right)=\cos \alpha_{0} \cdot \cos \vartheta_{2} \\
& m_{2 y}=-\sin \alpha_{0} ; m_{2 z}\left(\vartheta_{2}\right)=\cos \alpha_{0} \cdot \sin \vartheta_{2}
\end{aligned}
$$

where: $u_{2}, \quad 2$ are the linear and angular parameters of the wheel tooth flank.

Radius-vector $\bar{r}_{1}^{1}\left(u_{1}, \vartheta_{1}, \varphi_{1}\right)$ and normal unitary vector $\bar{m}_{1}^{1}\left(\vartheta_{1}, \varphi_{1}\right)$ projections of the gear tooth flank in coordinate system $S_{1}$, rigidly connected to the gear, taking into consideration formulas (9), (12) and (14), are described as follows:

$$
\begin{gathered}
x_{1}\left(u_{1}, \vartheta_{1}, \phi_{1}\right)=A \cdot \cos \left(\phi_{1}+\phi_{2}\right)+ \\
+B \cdot \sin \left(\phi_{1}+\phi_{2}\right)-a_{w s} \cdot \sin \phi_{1} ; \\
y_{1}\left(u_{1}, \vartheta_{1}, \phi_{1}\right)=-A \cdot \sin \left(\phi_{1}+\phi_{2}\right)+ \\
+B \cdot \cos \left(\phi_{1}+\phi_{2}\right)-a_{w s} \cdot \cos \phi_{1} ; \\
z_{1}\left(u_{1}, \vartheta_{1}\right)=\sin \vartheta_{1}\left(u_{1} \cdot \sin \alpha_{0}-r_{g 1}\right) \\
f\left(u_{1}, \vartheta_{1}, \phi_{1}\right)=u_{1} \cos \vartheta_{1}(1+i)+ \\
+\cos \alpha_{0} \cos \vartheta_{1}\left[R_{2 w}(1+i)-i a_{w s} \cos \phi_{2}\right]+ \\
+\sin \alpha_{0}\left[(1+i) r_{g 1}\left(1-\cos \vartheta_{1}\right)-i a_{w s} \sin \phi_{2}\right]=0 \\
m_{1 x}\left(\vartheta_{1}, \phi_{1}\right)=\cos \left(\phi_{1}+\phi_{2}\right) \cos \alpha_{0} \cos \vartheta_{1}- \\
-\sin \alpha_{0} \sin \left(\phi_{1}+\phi_{2}\right) ; \\
m_{1 y}\left(\vartheta_{1}, \phi_{1}\right)=-\sin \left(\phi_{1}+\phi_{2}\right) \cos \alpha_{0} \cos \vartheta_{1}- \\
-\sin \alpha_{0} \cos \left(\phi_{1}+\phi_{2}\right) ; \\
m_{1 z}\left(\vartheta_{1}\right)=\cos \alpha_{0} \cos \vartheta_{1},
\end{gathered}
$$

where: $A=\cos \vartheta_{1}\left(u_{1} \cdot \sin \alpha_{0}-r_{g 1}\right)+r_{g 1}$;

$B=u_{1} \cdot \cos \alpha_{0}+R_{2 w} ; \varphi_{1}=i \cdot \varphi_{2} ; u_{1}, \vartheta_{1}$ are the linear and angular parameters of the gear tooth flank; $\varphi_{1}$ is the gear rotation angle in forming the arc tooth flank on the basis of the generating wheel.

The gear movable links (gear and wheels) rotate around the axes $z_{1}$ and $z_{2}$. The gear and wheel are connected to coordinate systems $S_{1}$ and $S_{2}$. The starting point of the rotation angle $\psi_{k}$ of the $k^{\text {th }}$ mobile link $(k=$ $1,2)$ in operating meshing corresponds to the position of axis $y_{k}(k=1,2)$ in the axial plane of the gear. The relative position of the gear and wheel in operating meshing (in the absence of rotation) is characterized by center distance $a_{w p}$, angle $\eta$ of the teeth alignment error, teeth twist angle $\gamma$ and value of the wheel tooth mid- plane displacement $\delta S$ relative to the same plane on the gear tooth.

To study meshing of semi-rolled cylindrical arc teeth, we determine the position of coordinate system $S_{2}$ relative to system $S_{1}$ using fourth-order transition matrix $\tilde{D}_{1,2}\left(\psi_{1}, \psi_{2}\right)=\left\|d_{i, j}\right\|, i, j=\overline{1,4}$. The elements of this matrix have the following form:

$$
\begin{gathered}
d_{11}=c_{11} \cos \psi_{2}-c_{12} \sin \psi_{2} ; \\
d_{12}=c_{11} \sin \psi_{2}+c_{12} \cos \psi_{2} ; \\
d_{13}=\sin \psi_{1} \sin \gamma+\cos \psi_{1} \sin \eta \cos \gamma ; \\
d_{14}=-a_{w p} \sin \psi_{1}+\delta S \cdot c_{13} ; \\
d_{21}=c_{21} \cos \psi_{2}-c_{22} \sin \psi_{2} ; \\
d_{22}=c_{21} \sin \psi_{2}+c_{22} \cos \psi_{2} ; \\
d_{23}=\cos \psi_{1} \sin \gamma-\sin \psi_{1} \sin \eta \cos \gamma ; \\
d_{24}=-a_{w p} \cos \psi_{1}+\delta S \cdot c_{23} ; \\
d_{31}=-\sin \eta \cos \psi_{2}+\cos \eta \sin \gamma \sin \psi_{2} ; \\
d_{32}=-\sin \eta \sin \psi_{2}-\cos \eta \cos \gamma \cos \psi_{2} ; \\
d_{33}=\cos \eta \cos \gamma ; d_{34}=\delta S \cos \eta \cos \gamma ; \\
d_{41}=d_{42}=d_{43}=0 ; d_{44}=1,
\end{gathered}
$$

where: $c_{11}=\cos \psi_{1} \cos \eta$;

$c_{12}=\sin \psi_{1} \cos \gamma-\cos \psi_{1} \sin \eta \sin \gamma ;$

$c_{13}=\sin \psi_{1} \sin \gamma+\cos \psi_{1} \sin \eta \cos \gamma$;

$c_{21}=-\sin \psi_{1} \cos \eta$;

$c_{22}=\cos \psi_{1} \cos \gamma+\sin \psi_{1} \sin \eta \sin \gamma$;

$c_{23}=\cos \psi_{1} \sin \gamma-\sin \psi_{1} \sin \eta \cos \gamma$.

With $\gamma=\eta=\delta S=\delta a_{w}=0$ the elements of matrix $\tilde{D}_{1,2}\left(\psi_{1}, \psi_{2}\right)(20)$ coinside with the elements of matrix $\tilde{A}_{1,2}\left(\phi_{1}, \phi_{2}\right)$ (8). If the function of gear links displacement

$$
\psi_{2}=\psi_{2}\left(\psi_{1}\right)
$$

for given values $\gamma, \eta, \delta S$ and $a_{w p}$ is known, then, matrix $\widetilde{D}_{1,2}\left(\psi_{1}, \psi_{2}\right)$ describes a relative motion of the wheel and gear during the gear operation. In the nonenveloping gear, the law of parameter $\psi_{2}$ variation is established after determining the contact points of the active flanks of the gear and wheel teeth within the single-contact mesh. According to studies $[16,20]$ of the gearing theory, the contact point on the active flanks of the gear tooth for a fixed value of its rotation angle $\left(\psi_{1}\right.$ = const ) is determined by solving the inverse meshing problem $[20,31]$, the mathematical description of which is the following system of equations:

$$
\begin{gathered}
\tilde{r}_{1}^{1}\left(u_{1}, \vartheta_{1}, \phi_{1}\right)=\tilde{D}_{1,2}\left(\psi_{1}, \psi_{2}\right) \tilde{r}_{2}^{2}\left(u_{2}, \vartheta_{2}\right) ; \\
\tilde{m}_{1}^{1}\left(u_{1}, \vartheta_{1}, \phi_{1}\right)=\tilde{A}_{1,2}\left(\psi_{1}, \psi_{2}\right) \tilde{m}_{2}^{2}\left(u_{2}, \vartheta_{2}\right) ; \\
f\left(u_{1}, \vartheta_{1}, \phi_{1}\right)=0 .
\end{gathered}
$$

Here, the superscript defines the coordinate system in which the vector projections are calculated; $\widetilde{r}_{2}^{2}, \widetilde{m}_{2}^{2}$ are columns matrixes made up of the coordinate projec- 
tions of radius-vector $\bar{r}_{2}^{2}(15)$ and normal unitary vector $\bar{m}_{2}^{2}$ (16) of the wheel tooth active flank in coordinate system $S_{2} ; \tilde{r}_{1}^{1}, \tilde{m}_{1}^{1}$ are columns matrixes made up of the coordinate projections of radius-vector $\bar{r}_{1}^{1}$ (17) and normal unitary vector $\bar{m}_{1}^{1}$ (19) of the wheel tooth active flank in coordinate system $S_{1} ; f\left(u_{1},{ }_{1}, \varphi_{1}\right)=0$ is the equation of meshing in processing the gear teeth flank (18).

System (22) corresponds to the conditions of the correct contact of the gear and wheel teeth active flanks and is equivalent to six scalar transcendental equations (the equality of normal unitary vectors only gives two independent equations) with seven unknowns $u_{1}, \quad{ }_{1}, \varphi_{1}$, $u_{2}, \psi_{1}, \psi_{2}$ :

$$
\begin{gathered}
x_{1}\left(u_{1}, \vartheta_{1}, \phi_{1}\right)-d_{11}\left(\psi_{1}, \psi_{2}\right) x_{2}\left(u_{2}, \vartheta_{2}\right)= \\
=d_{12}\left(\psi_{1}, \psi_{2}\right) y_{2}\left(u_{2}\right)+d_{13}\left(\psi_{1}\right) z_{2}\left(u_{2}, \vartheta_{2}\right)+d_{14}\left(\psi_{1}\right) ; \\
y_{1}\left(u_{1}, \vartheta_{1}, \phi_{1}\right)-d_{21}\left(\psi_{1}, \psi_{2}\right) x_{2}\left(u_{2}, \vartheta_{2}\right)= \\
=d_{22}\left(\psi_{1}, \psi_{2}\right) y_{2}\left(u_{2}\right)+d_{23}\left(\psi_{1}\right) z_{2}\left(u_{2}, \vartheta_{2}\right)+d_{24}\left(\psi_{1}\right) ; \\
z_{1}\left(u_{1}, \vartheta_{1}\right)-d_{31}\left(\psi_{2}\right) x_{2}\left(u_{2}, \vartheta_{2}\right)= \\
=d_{32}\left(\psi_{2}\right) y_{2}\left(u_{2}\right)+d_{33}\left(\psi_{2}\right) z_{2}\left(u_{2}, \vartheta_{2}\right)+d_{34} ; \\
m_{1 x}\left(\vartheta_{1}, \phi_{1}\right)-d_{11}\left(\psi_{1}, \psi_{2}\right) m_{2 x}\left(\vartheta_{2}\right)= \\
=d_{12}\left(\psi_{1}, \psi_{2}\right) m_{2 y}+d_{13}\left(\psi_{1}\right) m_{2 z}\left(\vartheta_{2}\right) ; \\
m_{1 z}\left(\vartheta_{1}\right)-d_{31}\left(\psi_{2}\right) m_{2 x}\left(\vartheta_{2}\right)= \\
=d_{32}\left(\psi_{2}\right) m_{2 y}+d_{33} m_{2 z}\left(\vartheta_{2}\right) ; f\left(u_{1}, \vartheta_{1}, \phi_{1}\right)=0 .
\end{gathered}
$$

To determine the coordinates of the contact point of the gear and wheel teeth flanks with specified errors of the relative position $(\gamma, \eta, \delta S)$ of the gear and the wheel. It is sufficient to fix the meshing phase $\left(\psi_{1}=\right.$ const $)$ within the gear tooth spacing angle and solve a system of six transcendental equations (23) relative to the unknowns $u_{1}, \quad 1, \varphi_{1}, u_{2}, \psi_{1}, \psi_{2}$.

The solution of the system (23) is performed numerically using the program developed in MathCad.

\section{STUDY OF ARC TEETH SEMI-ROLLED CYLINDRICAL GEAR MESHING}

The developed program allows calculating the points of the line of action in meshing (working line) of the arc teeth semi-rolled cylindrical gear and the impact of errors in the gear and wheel relative position on the position of the working line. The coordinates of the points of this line are required for calculating the load distributed in the contact of arc teeth.

We regard the results of the analysis on an example of studying a gear that has the following parameters: $z_{1}^{*}=23 ; z_{2}^{*}=73$; the normal module is $m_{n}=10 \mathrm{~mm}$; the displacement coefficients, when cutting the gear and wheel teeth, are $\chi_{1}=0,44$ and $\chi_{2}=0,42$ repectively; the tooth width is $b_{w}=120 \mathrm{~mm} ; \alpha_{0}=20^{\circ}$, the radii of the initial circle of the gear and wheel are $R_{w 1}=116,115$ $\mathrm{mm}$ and $R_{w 1}=368,540 \mathrm{~mm}$ respectively, the center distance is $a_{w}=484,655 \mathrm{~mm}$. The calculations were performed for two variants of contact localization in the longitudinal direction of the arc teeth. In variant 1 (high localization), to cut the concave side of the gear arc teeth and the convex side of the wheel arc teeth, circular cutting heads with calculated radii of $r_{g 1}=200 \mathrm{~mm}$ and $r_{g 2}=215 \mathrm{~mm}$ are used. In variant 2 (contact close to linear one) the radii are $r_{g 1}=200 \mathrm{~mm}$ and $r_{g 2}=218 \mathrm{~mm}$.

Figure 5 shows active lines of action on the flank of the gear tooth of the studied gear (variant 1) with the alignment error of the gear and wheel axes: $\eta=0\left(0^{\prime}\right)$; $0,0003\left(1^{\prime}\right) ; 0,0009\left(3^{\prime}\right) ; 0,0015\left(5^{\prime}\right)$ and $0.0021\left(7^{\prime}\right)$.

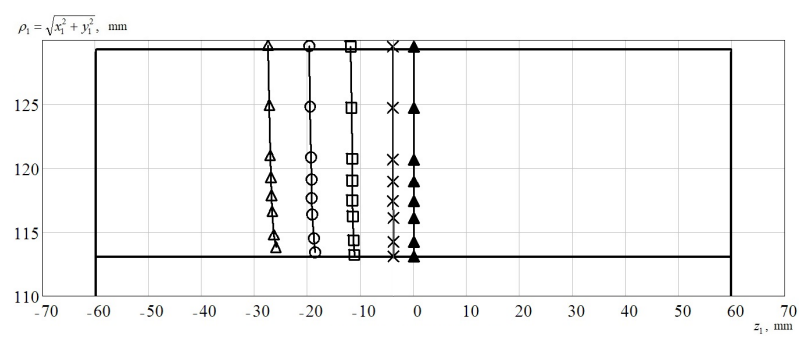

Figure 5. Active lines of action in meshing $\eta=0 \quad(\Delta) ; 1^{\prime}$ $(\times) ; 3^{\prime}(\square) ; 5^{\prime}(\circ)$ and $7^{\prime}(\Delta)$ (variant 1)

Figure 6 shows active lines of action in meshing with $\eta=0^{\prime} ; 1^{\prime} ; 3^{\prime} ; 5^{\prime}$ and $7^{\prime}$ for variant 2 .

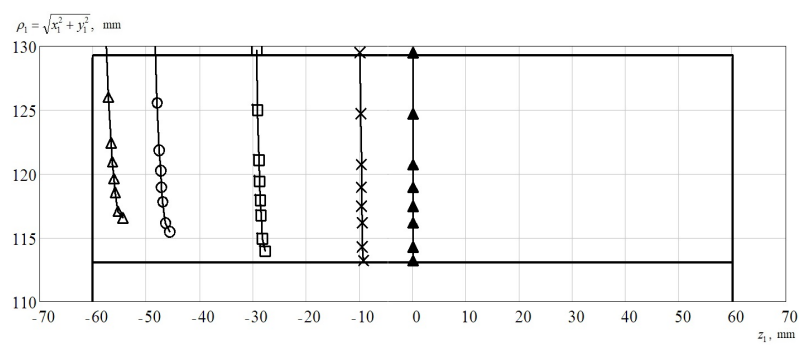

Figure 6. Active lines of action in meshing $\eta=0 \quad(\Delta) ; 1^{\text {. }}$ $(\times) ; 3^{\prime}(\square) ; 5^{\prime}(\circ)$ and $7^{\prime}(\Delta)$ (variant 2)

Figure 7 illustrates the position of active lines of action on the flank of the gear tooth of the studied gear (variant 1) when the gear and wheel axes are twisted; $\gamma=0^{\prime} ; 1^{\prime} ; 3^{\prime} ; 5^{\prime}$ and $7^{\prime}$.

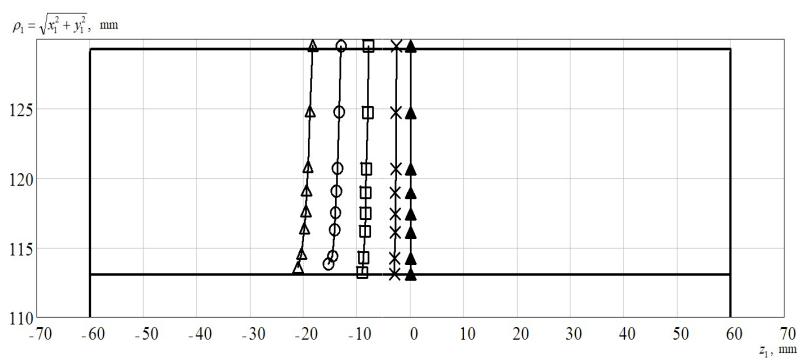

Figure 7. Active lines of action in meshing $\gamma=0(\Delta)$; 1 ' $(\times)$; 3' (口);5' (०) and 7' $(\Delta)$ (variant 1)

Figure 8 represents active lines of action in meshing with $\gamma=0^{\prime} ; 1^{\prime} ; 3^{\prime} ; 5^{\prime}$ and $7^{\prime}$ for variant 2

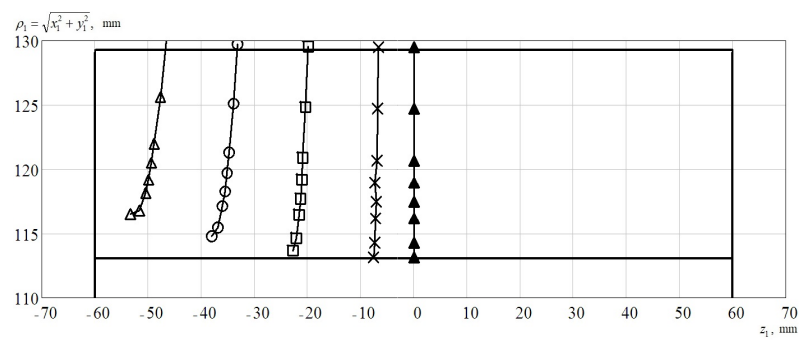

Figure 8. Active lines of action in meshing $\gamma=0$ ( $\Delta)$; $1^{\prime}$ $(\times) ; 3^{\prime}(\square) ; 5^{\prime}(\circ)$ and $7^{\prime}(\Delta)$ (variant 2) 
Figure 9 shows the position of the active lines of action in the arc teeth semi-rolled cylindrical gear (variant 1) with the axis displacement of the gear relative to the wheel by $\delta S=0,0 ;-0,1 ;-0,2 ;-0,3 ;-0,4 \mathrm{~mm}$.

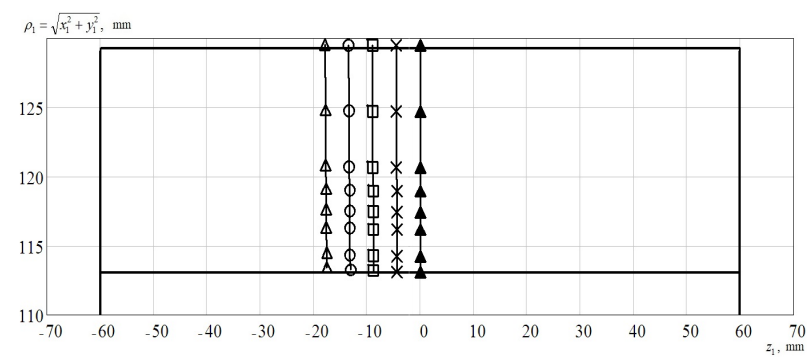

Figure 9. Active lines of action in meshing $\delta S=0(\Delta) ;-0,1$ $(\times) ;-0,2(\square) ;-0,3(\circ)$ and $-0,4 \mathrm{~mm}(\Delta)$ (variant 1)

Figure 10 illustrates the position of active lines of action in the arc teeth semi-rolled cylindrical gear (variant 2) with the axis displacement of the gear relative to the wheel by $\delta S=0,0 ;-0,1 ;-0,2 ;-0,3 ;-0,4 \mathrm{~mm}$.

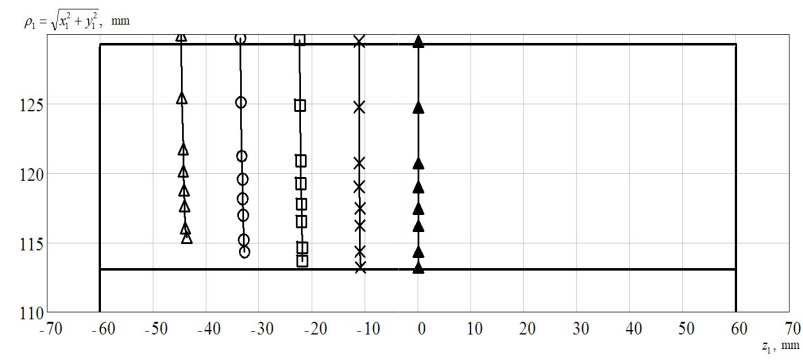

Figure 10. Active lines of action in meshing $\delta S=0(\Delta) ;-0,1$ $(\times) ;-0,2(\square) ;-0,3(\circ)$ and $-0,4 \mathrm{~mm}(\Delta)$ (variant 2)

\section{CONCLUSION}

In this paper, mathematical models of the processes of forming the flanks of semi-rolled cylindrical gear arc teeth of the wheel and gear have been built. An algorithm and a program to calculate the coordinates of the points of the active line of action in meshing arc teeth have been worked out. Calculations have been performed to estimate the variations in active lines of action with various errors in the relative position of the gear and wheel.

The analysis of the calculations (Figure 5... Figure 10) shows that when the contact of the arc teeth flanks is close to linear $\left(r_{g 1}=200 \mathrm{~mm}\right.$ and $\left.r_{g 2}=218 \mathrm{~mm}\right)$, the gear sensitivity to errors in the relative position of the wheel and gear significantly increases compared to the localized contact $\left(r_{g 1}=200 \mathrm{~mm}\right.$ and $\left.r_{g 2}=215 \mathrm{~mm}\right)$. The effect of the teeth twist angle $\gamma$ on the position of active lines of acvtion in meshing arc teeth of the gear and wheel (Figure 7 and Figure 8 ) is almost analogous to the effect of alignment error $\eta$ (Figure 5 and Figure 6). An increase of longitudinal contact localization in arc teeth meshing (Figure 9 and Figure 10) reduces the sensitivity of the gear to axial displacement of the gear relative to the wheel.

The calculated geometric characteristics of arc teeth meshing in the presence of errors in the relative position of the wheel and gear are required to calculate the load capacity and durability of the gear.

\section{REFERENCES}

[1] Syzrantseva K.V., Syzrantsev V.N. and Kolbasin D.S.: Comparative estimation of the failure probability of cylindrical arc and helical gears by tooth bending endurance, AIP Conference Proceedings, Vol. 2176, Paper 020010, 2019, https://doi.org $/ 10.1063 / 1.5135122$.

[2] Syzrantseva K.V., Syzrantsev V.N., Babichev D.T.: Comparative analysis of stress-strain condition of cylindrical gears arc teeth and spurs, Lecture Notes in Mechanical Engineering, pp. 101-108, 2020, https://doi.org/10.1007/978-3-030-22041-9_12.

[3] Litvin, F. L., Petrov, K. M. and Ganshin, V. A.: The effect of geometrical parameters of hypoid and spiroid gears on their quality characteristics, ASME Journal of Engineering for Industry, Vol. 96, pp.330-334, 1974.

[4] Litvin, F. L., Fuentes, A., Zanzi, C., Pontiggia, M. and Handschuh, R. F.: Face gear drive with spur involute pinion: geometry, generation by a worm, stress analysis, Computer Methods in Applied Mechanics and Engineering, Vol. 191, pp. 27852813, 2002.

[5] Fuentes, A., Litvin, F. L., Mullins, B. R., Woods, R. and Handschuh, R. F.: Design and stress analysis of low-noise adjusted bearing contact spiral bevel gears, ASME Journal of Mechanical Design, Vol. 124 (Sep.), pp. 524-532, 2002.

[6] Szávai, S. and Kovács, S.: EHD contact modelling of Gleason bevel gears, FME Transactions, Vol. 43, pp. 233-240, 2015, doi: 10.5937/fmet1503233S.

[7] Litvin, F. L. and Fuentes, A.: Gear geometry and applied theory, Cambridge: University Press, New York, 2004.

[8] Stadtfeld, H. J.: Handbook of bevel and hypoid gears. Calculation - Manufacturing - Optimization, Rochester Institute of Technology, NY, 1993.

[9] Litvin, F. L.: Development of gear technology and theory of gearing, NASA Reference Publication 1406, 1997.

[10] Stadtfeld, H. J: Gleason bevel gear technology. manufacturing, inspections and optimization: Collected Publications 1994/95. The Gleason Works, Rochester, New York (USA), 1995.

[11] Kawasaki, K.: Manufacturing method for largesized bevel gears in cyclo-palloid system using multi-axis control and multi-tasking machine tool, in: Proceedings of International Conference on Gears, 2010, Munich, VDI-Berichte 2108.1, pp. 337-348.

[12]Lelkes, M., Márialigeti, J. and Play, D.: Numerical determination of cutting parameters for the control of Klingelnberg spiral bevel gear geometry, Journal of Mechanical Design, Transactions of the ASME, 124 (4), pp. 761-771, 2002.

[13] Du, J. and Fang, Z.: An active tooth surface design methodology for face-hobbed hypoid gears based on measuring coordinates, Mechanism and Machine Theory, Vol. 99, pp. 140-154, 2016. 
[14] Shih, Y.-P., Fong, Z.-H. and Lin, G.C.Y.: Mathematical model for a universal face hobbing hypoid gear generator, Journal of Mechanical Design, Transactions of the ASME, Vol. 129(1), pp. 38-47, 2007.

[15] Shih, Y.-P. and Fong, Z.-H.: Flank modification methodology for face-hobbing hypoid gears based on ease off topography, Journal of Mechanical Design, Transactions of the ASME, Vol. 129(12), pp. 1294-1302, 2007.

[16] Litvin, F. L. and Gutman, Y.: Methods of synthesis and analysis for hypoid gear drives of formate and helixform. Parts 1, 2, and 3, ASME Journal of Mechanical Design, Vol. 103, No 1, pp.83-113, 1981.

[17]Litvin, F. L. and Gutman, Y.: A method of local synthesis of gears based on the connection between the principal and geodetic curvatures of surfaces, ASME Journal of Mechanical Design, Vol. 103, 1981.

[18]Fan, Q.: Computerized modeling and simulation of spiral bevel and hypoid gears manufactured by Gleason face hobbing process, Journal of Mechanical Design, Transactions of the ASME, Vol. 128 (6), pp. 1315-1327, 2006.

[19] Radzevich S.P.: Theory of gearing: kinematics, geometry, and synthesis, 2nd Edition, CRC Press, Boca Raton, Florida, 712 p, 2018.

[20] Syzrantsev, V., Syzrantseva, K. and Varshavsky, M.: Contact load and endurance of cylindrical gearing with arch-shaped teeth, in: Proceedings of the International Conference on Mechanical Transmissions, 05-09.04.2001, Chongqing, China, pp. 425-431.

[21] Arafa, H.A.: C-gears: Geometry and machining, Proceedings of the Institution of Mechanical Engineers, Part C: Journal of Mechanical Engineering Science, Vol. 219, Iss. 7, pp. 709-726, 2005.

[22] Arafa, H.A. and Bedewy, M.: Manufacturability and viability of different c-gear types: A comparative study, in: Proceedings of the ASME Design Engineering Technical Conference, 12.08.2012, Chicago, IL, United States, Vol. 5, pp. 381-391.

[23]Liu, Sh.-T.: Curvilinear cylindrical gears, Gear Technology, Vol. 5, Iss. 3, pp. 8-12, 1988.

[24] Yi-Qiang Jiang, Li Hou and Yong Zhao.: The equation of the contact line of the involute curvilinear-tooth cylindrical gear pump for the agricultural tractor, The Open Mechanical Engineering Journal, Vol. 8, pp.879-884, 2014.

[25] Tsay, C.-B.: Equations for helical gears with pinion circular arc teeth and gear involute teeth, Journal of the Chinese Institute of Engineers, Transactions of the Chinese Institute of Engineers, Series A/C, Vol. 10, Iss. 1, pp. 45-51, 1987.

[26] Tsay, G.-B., Fong, Z.H.: Tooth contact analysis for helical gears with pinion circular arc teeth and gear involute shaped teeth, Journal of Mechanical Design, Transactions of the ASME, Vol. 111, Iss. 2, pp. 278-284, 1989.

[27] Bobkov M.N., Sheinin G.M. and Polyakov V.V.: Overlap in semigenerated cylindrical transmissions round teeth, Russian Engineering Research, Vol. 31, Iss. 12, pp. 1266-1267, 2011.

[28]Bobkov M.N., Sheinin G.M. and Polyakov V.V.: Tip thickness of circular tooth at the end of a pinion in a semirolling cylindrical transmission, Russian Engineering Research, Vol. 30, Iss. 7, pp. 747-748, 2010.

[29] Tseng, J.-T. and Tsay,C.-B.: Mathematical model and surface deviation of cylindrical gears with curvilinear shaped teeth cut by hob cutter, Journal of Mechanical Design, Transactions of the ASME. Vol. 127, Iss. 5, pp. 982-987, 2005.

[30] Dai, Y., Yukinori, A. Jiang, D.: Hobbing mechanism of cylindrical gear with arcuate tooth traces and experimental investigation, China Mechanical Engineering, Vol. 17, Iss. 7, pp. 706-709, 2006.

[31] Syzrantsev V., Syzrantseva K., Pazyak A. and Milanovic M.: Research on geometrical characteristics of straight bevel gears with a small shaft angle with a non-generated gear and generated pinion, FME Transactions, Vol. 45, Iss. 4, pp. 661-669, 2017, doi: 10.5937/fmet1704661S.

\section{ПРОУЧАВАЊЕ ГЕОМЕТРИЈСКИХ КАРАКТЕРИСТИКА СПРЕЗАЫА ПОЛУВАљАНИХ ЦИЛИНДРИЧНИХ ЗУПЧАНИКА СА ЛУЧНИМ ЗУПЦИМА}

\section{В.Н. Сизранцев, К.В. Сизранцева}

У условима непричвршћених делова машине цилиндрични зупчаници са лучним зупцима имају већи капацитет оптерећења, трајност и поузданост, као и капацитет да компензују угао увијања самоприлагођавањем једног од зупчаника у поређењу са правозубим и хеликоидним зупчаницима. Употреба таквих зупчаника у полуваљаној верзији значајно поједностављује технолошки процес резања и израде зупчаника са великим преносним односом. У раду је приказан математички модел зупчаника и процес израде лучних зубаца за полуваљани цилиндрични зупчаник. Геометријске карактеристике спрезања зупчаника уз присуство грешке код зупчаника и релативног положаја зупчаника намећу потребу решавања проблема израчунавања капацитета оптерећења и трајности зупчаника, што је у раду и учињено. 